\title{
A Comparative Study on the Utilization of Corn Pericarp and Peanut Hull in the Production of Ethanol and the Impact on Food Economics
}

\author{
J. L. Herring*, V. C. Narayanan \\ Department of Food \& Animal Sciences, Alabama A\&M University, Normal, AL, USA \\ Email: *josh.herring@aamu.edu
}

How to cite this paper: Herring, J.L. and Narayanan, V.C. (2016) A Comparative Study on the Utilization of Corn Pericarp and Peanut Hull in the Production of Ethanol and the Impact on Food Economics. Food and Nutrition Sciences, 7, 1010-1020. http://dx.doi.org/10.4236/fns.2016.711098

Received: August 9, 2016

Accepted: September 20, 2016

Published: September 23, 2016

Copyright $\odot 2016$ by authors and Scientific Research Publishing Inc. This work is licensed under the Creative Commons Attribution International License (CC BY 4.0).

http://creativecommons.org/licenses/by/4.0/

\begin{abstract}
Corn pericarp and peanut hull (lignocellulosic materials) which are food industry by-products were used as substrates in this study. Alkaline hydrogen peroxide $\left(\mathrm{H}_{2} \mathrm{O}_{2}\right)$ pretreatments at $0 \%, 2.5 \%$ and $5 \%$ were used for the removal of lignin. Simultaneous Saccharification and Fermentation (SSF) and Separate Hydrolysis and Fermentation (SHF) were conducted using Aspergillus niger (strain 201201) and Saccharomyces cerevisiae (strain 26603). Aspergillus niger was added on day 1 to all samples with inoculation treatments of $S$. cerevisiae at one-day intervals $(\mathrm{A}=$ Day $1, \mathrm{~B}=$ Day $2, \mathrm{C}=$ Day 3 and $\mathrm{D}=$ Day 4). Pretreatment with $2.5 \% \mathrm{H}_{2} \mathrm{O}_{2}$ was more beneficial in the removal of lignin for both substrates. Corn pericarp yielded an ethanol concentration of $22.2 \mathrm{~g} / \mathrm{L}$ in $\mathrm{C}$ and $21.78 \mathrm{~g} / \mathrm{L}$ in D of $2.5 \% \mathrm{H}_{2} \mathrm{O}_{2}$ pretreatment. Peanut hull with $2.5 \%$ $\mathrm{H}_{2} \mathrm{O}_{2}$ pretreatment in $\mathrm{D}$ yielded a higher concentration at $10.38 \mathrm{~g} / \mathrm{L}$ compared to other inoculation treatments. The highest ethanol yielded on a percentage basis for corn pericarp was $45.04 \%$ in $\mathrm{C}$ of $2.5 \% \mathrm{H}_{2} \mathrm{O}_{2}$ pretreatment and $24.6 \%$ in D of $2.5 \%$ $\mathrm{H}_{2} \mathrm{O}_{2}$ pretreatment for peanut hull.
\end{abstract}

\section{Keywords}

Ethanol, Peanut Hull, Corn Pericarp, Alkaline Pretreatment, Fermentation

\section{Introduction}

The Consumer Price Index (CPI) for food commodities is projected to increase by 0.25 1.0 percent in 2016. This increase is below the 20-year average of 2.5. The CPI is expected to near 2.0 percent by 2017 [1]. Increases are due to increases in the global population, cost of production and processing of food products, commodity transportation costs and natural calamities which damage crops. In the United States liquid fuel usage 
increased by approximately $1.5 \%$ in 2015 and gasoline usage alone is projected to increase by at least $1.5 \%$ in 2016 . This would be the highest annual usage average since 2007 [2].

Many countries face a scarcity of fuel with the available fuel increasing in cost because of the unavailability of a low cost alternate [3]. With the exception of a few countries, global dependence on fossil fuels is only quenched with Middle East supplies. Due to diminishing natural resources and increasing demands, the world is trying to find alternative sources for fossil fuels.

The U.S. CPI for all items by $5.4 \%$ but all food rose $8.5 \%$ and was only third to medical care and housing from 2011-2015 [4]. Food prices have a high correlation with oil prices as presented in Figure 1 by Chen et al. [5].

From the food industry sector a wide variety of byproducts and waste products, like corn pericarp and peanut hull, are generated. As there is a lot of waste between the producer and consumer it must be recognized that if industries are able to recycle their waste products into a value-added products like bio diesel and bio ethanol, they could recoup fuel expenses for the transportation of their commodities to the consumer. The objective of this research was to investigate the efficiency of producing ethanol from food waste streams.

\section{Materials and Methods}

\subsection{Reagents, Raw Materials and Chemicals}

Reagents for pretreatment and analysis were obtained from Fisher Scientific. HPLC reference standards and chemicals were obtained from Sigma Aldrich. Corn pericarp was obtained from the Food Engineering Pilot Plant (Alabama A\&M University) as a

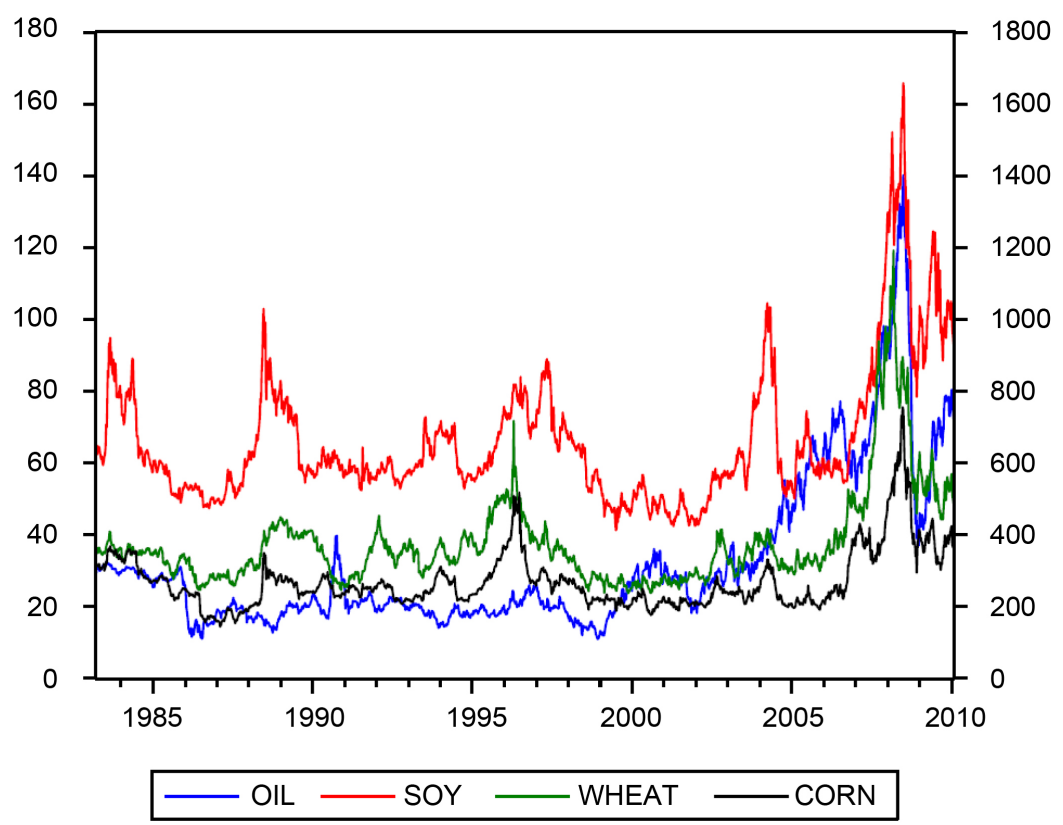

Figure 1. The relationship between the grain futures prices and the oil price [5]. 
byproduct of the corn milling process and peanut hull was procured from Biosystem Engineering (Auburn University, AL, USA).

\subsection{Yeast Growth}

Aspergillus niger (strain 201201) and Saccharomyces cerevisiae (strain 26603) were procured from American Type Culture Collection (ATCC), Virginia, USA and was maintained on potato dextrose agar slants (Difco Laboratories, Detroit, MI) and stored at $4^{\circ} \mathrm{C}$.

\subsection{Preparation of Inocula}

A. niger inocula were prepared by using slant cultures to inoculate $50 \mathrm{ml}$ of sterile growth medium (Potato Dextrose Broth (PDB)) contained in $250 \mathrm{ml}$ stoppered Erlenmeyer flasks. The flasks were incubated with shaking $(200 \mathrm{rpm})$ in a water bath shaker at $30^{\circ} \mathrm{C}$ for 5 days (Abauzied and Reddy 1986). S. cerevisiae inoculum was prepared in the same way as A. niger in PDB and was incubated for $24 \mathrm{~h} \mathrm{[6].}$

\subsection{Substrate Preparation}

Peanut hull and corn pericarp were dried in a hot air oven for $24 \mathrm{~h}$ at $60^{\circ} \mathrm{C}$ and were ground with the use of a Wiley mill (Scientific apparatus, PA, USA) with a mesh size of 2 - $4 \mathrm{~mm}$. These powdered materials were subjected to alkali pretreatment separately. Samples of peanut hull were weighed $(10 \mathrm{~g})$ and placed in three beakers. Subsequently 2.5\% $\mathrm{H}_{2} \mathrm{O}_{2}$ solution was also prepared. The $\mathrm{pH}$ of the $\mathrm{H}_{2} \mathrm{O}_{2}$ solution was adjusted to 12 by adding sodium hydroxide $(1 \mathrm{~N})$ solution. Hydrogen peroxide solution (approximately $75 \mathrm{ml}$ ) was added to the beakers to submerge the peanut hull and was mixed thoroughly and allowed to soak for $24 \mathrm{~h}$. This experiment was repeated for $\mathrm{H}_{2} \mathrm{O}_{2}$ concentrations of $0 \%$ and $5 \%$. Deionized (DI) water was substituted for $\mathrm{H}_{2} \mathrm{O}_{2}$ for the $0 \%$ treatment level. Each $\mathrm{H}_{2} \mathrm{O}_{2}$ treatment was repeated three times. After the $24 \mathrm{~h}$ treatment, the residue was removed from the solution by filtering through a piece of cheesecloth. The residue was oven dried at $60^{\circ} \mathrm{C}$ for approximately $24 \mathrm{~h}$ and the weight recorded. The same treatment was repeated for the corn pericarp and the residues were used for the fermentation process.

\subsection{Fermentation Procedure}

Dried samples were added to distilled water in the ratio of 1 in $10 \mathrm{w} / \mathrm{v}$. Slurry $\mathrm{pH}$ was adjusted to 4.5 , addition of $1 \mathrm{~N} \mathrm{NaOH}$ or $1 \mathrm{~N} \mathrm{HCl}$ and autoclaved at $120^{\circ} \mathrm{C}$ for $50 \mathrm{~min}$ for sterility [7]. Six fermentation processes with the use of $0 \%, 2.5 \%$ and $5 \%$ alkaline pretreated corn pericarp and peanut hull were conducted. Anaerobic inoculation of $A$. niger culture was done to all inoculation treatments on day 1 itself but $S$. cerevisiae was inoculated to inoculation treatment A on day 1, to B on day 2, to C on day 3 and to D on day 4 . Both $A$. niger and $S$. cerevisiae were inoculated into the slurry with the proportion of $10 \% \mathrm{v} / \mathrm{v}$. Samples were collected aseptically on days $1,2,3,4,5,6,7$ and 8 using a $5 \mathrm{~mL}$ syringe. The samples were centrifuged at $5000 \mathrm{rpm}$ for $10 \mathrm{~min}$ with the 
use of Sorvall (RC 26 plus) centrifuge and $2 \mathrm{ml}$ supernatant fluid was stored in screw capped vials at $-4^{\circ} \mathrm{C}$ for further analysis [6].

\subsection{Reducing Sugars}

The reducing sugar estimation of the supernatant fluid was determined with the use of a dinitrophenol method [8].

\subsection{Ethanol Yield}

A high performance liquid chromatography system (Beckman System Gold, Programmable solvent module 126) was used to determine the ethanol concentration in the fermented samples. A Bio-Rad Aminex column (Bio-Rad, Richmond, CA) and a refractive index detector (Beckman 156) were used. Sulfuric acid at $5 \mathrm{mmol} / \mathrm{L}$ was used as the mobile phase at a flow rate of $0.4 \mathrm{ml} / \mathrm{min}$, and the column temperature was maintained at $55^{\circ} \mathrm{C}$ (Shen and others 2008) [9]. Retention time for ethanol was $24.2 \mathrm{~min}$. A standard curve for ethanol was constructed using $200^{\circ}$ proof ethanol at $2 \%, 4 \%, 6 \%, 8 \%$ and $10 \% \mathrm{w} / \mathrm{v}$ concentrations. The area counts (area under the peak) of ethanol in the chromatogram for each sample were recorded and the ethanol concentration $(\mathrm{g} / \mathrm{L})$ was calculated from the regression equation of the ethanol standard curve with $\mathrm{R}^{2}=0.9954$;

$$
Y=0.0079 X
$$

where:

$Y=$ area count;

$X=$ concentration of ethanol $(\mathrm{g} / \mathrm{L})$.

The theoretical ethanol yield with $100 \%$ efficiency was calculated assuming complete conversion of glucose, obtained from cellulose hydrolysis, to ethanol, where by $180 \mathrm{~g}$ of glucose $(1 \mathrm{~mol})$ yield $92 \mathrm{~g}$ of ethanol $(2 \mathrm{~mol})$. This value was compared with the estimated ethanol content obtained with the use of HPLC. Then the ethanol yield and the percentage efficiency of the fermentation process was calculated [6].

The yield of ethanol was calculated using the formula:

$$
Y=\left(\frac{0.9 * E}{0.51 * S}\right) * 100
$$

where:

$Y=$ Yield of ethanol (\%);

$E=$ Ethanol concentration $(\mathrm{g} / \mathrm{L})$;

$S=$ Carbohydrate (cellulose and hemicellulose) concentration in substrate $(\mathrm{g} / \mathrm{L})$.

Theoretically $90 \%$ of the cellulose is getting converted into ethanol on fermentation. When $1 \mathrm{~g}$ of glucose is metabolized, the weight of ethanol and carbon dioxide produced will be $0.51 \mathrm{~g}$ and $0.49 \mathrm{~g}$ respectively [10] [11].

\subsection{Experimental Design and Data Analysis}

Corn pericarp and peanut hull samples were treated with three concentrations of $\mathrm{H}_{2} \mathrm{O}_{2}$ $(0 \%, 2.5 \%$ and $5 \%)$ and were designated as main treatments. Four levels of sub treat- 
ments (A, B, C and D which denoted lag time for inoculating with $S$. cerevisiae-day 1 , day 2, day 3 and day 4 respectively) were performed in triplicates. From each treatment, samples were collected on days 1, 2, 3, 4, 5, 6, 7 and 8 for the quantification of ethanol and reducing sugar. To account for the variations in the concentration of reducing sugar and ethanol with respect to pretreatment conditions, inoculation treatments and interaction effects, factorial design of experiment was used. The results were expressed as mean values \pm standard deviation (SD). The results were analyzed using one way analysis of variance (ANOVA) followed by Tukey's t-test at $P \leq 0.05$ using SAS 9.1.3.

\section{Results and Discussion}

\subsection{Corn Pericarp-Alkaline Pretreatment and Lignin Loss}

Corn pericarp substrate subjected for alkaline pretreatment with $2.5 \% \mathrm{H}_{2} \mathrm{O}_{2}$ showed maximum removal of lignin which was significantly higher $(P<0.05)$ when compared to $0 \%$ and $5 \% \mathrm{H}_{2} \mathrm{O}_{2}$ treated samples. Samples treated with $2.5 \%$ and $5 \% \mathrm{H}_{2} \mathrm{O}_{2}$ resulted in $12.92 \%$ and $10.76 \%$ weight loss, respectively.

Results from this study are similar to those of Dawson and Boopathy [12] who alkaline pretreated sugar cane leaf with $\mathrm{H}_{2} \mathrm{O}_{2}$ and Gould [13] who pretreated wheat straw and reported increases in lignin reduction and glucose yields.

\subsection{Peanut Hull-Alkaline Pretreatment and Lignin Loss}

Peanut hull substrate pretreated with $2.5 \% \mathrm{H}_{2} \mathrm{O}_{2}$ had the highest amount of lignin removed $(P<0.05)$ when compared to $5 \%$ and $0 \%$ treatments. The results showed that the lignin degradation gradually decreased as the concentration of $\mathrm{H}_{2} \mathrm{O}_{2}$ increased. These results are similar to previous studies with varying concentrations of $\mathrm{H}_{2} \mathrm{O}_{2}$ [12] [14]. Lignin forms a protective shield around cellulose, guarding it from enzymatic action and at the same time increases the crystallinity of cellulose [15] [16].

\subsection{Corn Pericarp-Reducing Sugar (RS)}

Because of the utilization of reducing sugar by fermenting organisms, various inoculation treatments of $0 \%$ pretreated corn pericarp (A, B, C and D) showed an increase and decrease in the reducing sugar concentrations as fermentation progressed (Figure 2). Day 1 values for reducing sugar indicated its initial concentration. There were no significant differences $(P<0.05)$ in the initial concentration of RS between inoculation treatments. Kang and others [17] reported that the activity of the cellulase system produced by $A$. niger would yield the highest level of RS on day 4 of fermentation and after that the rate of hydrolysis will show a downward trend. The results obtained in the study also showed similar trend in the activity of cellulose enzyme. Inoculation treatment $\mathrm{D}$ on day 4 of fermentation yielded the highest amount of RS $(8.3 \mathrm{~g} / \mathrm{L})$ compared to other treatments. In the inoculation treatment $\mathrm{D}$, cellulase enzyme systems produced by $A$. niger were able to break down cellulose and hemicelluloses continuously for 4 days of fermentation resulting in a high amount of glucose. The figure also shows decrease in the RS concentrations after inoculation with $S$. cerevisiae in to the corres- 
ponding inoculation treatments as the fermentation progresses. This trend was observed in the $2.5 \%$ and $5.0 \%$ pretreated samples.

\subsection{Peanut Hull-Reducing Sugar (RS)}

Peanut hull samples pretreated with $2.5 \% \mathrm{H}_{2} \mathrm{O}_{2}$ yielded the highest concentration of RS $(17.92 \mathrm{~g} / \mathrm{L})$ in inoculation treatment $\mathrm{D}$ on day 4 (Figure 3 ). There were no significant differences between the initial concentration of RS (day 1) and that on the day of termination of the fermentation process (day 8). A reduction of $80 \%$ of RS concentration recorded on day 4 was observed on day 8 which indicated possible conversion of RS to ethanol during fermentation. This trend was observed in $0 \%$ and $5 \% \mathrm{H}_{2} \mathrm{O}_{2}$ pretreated

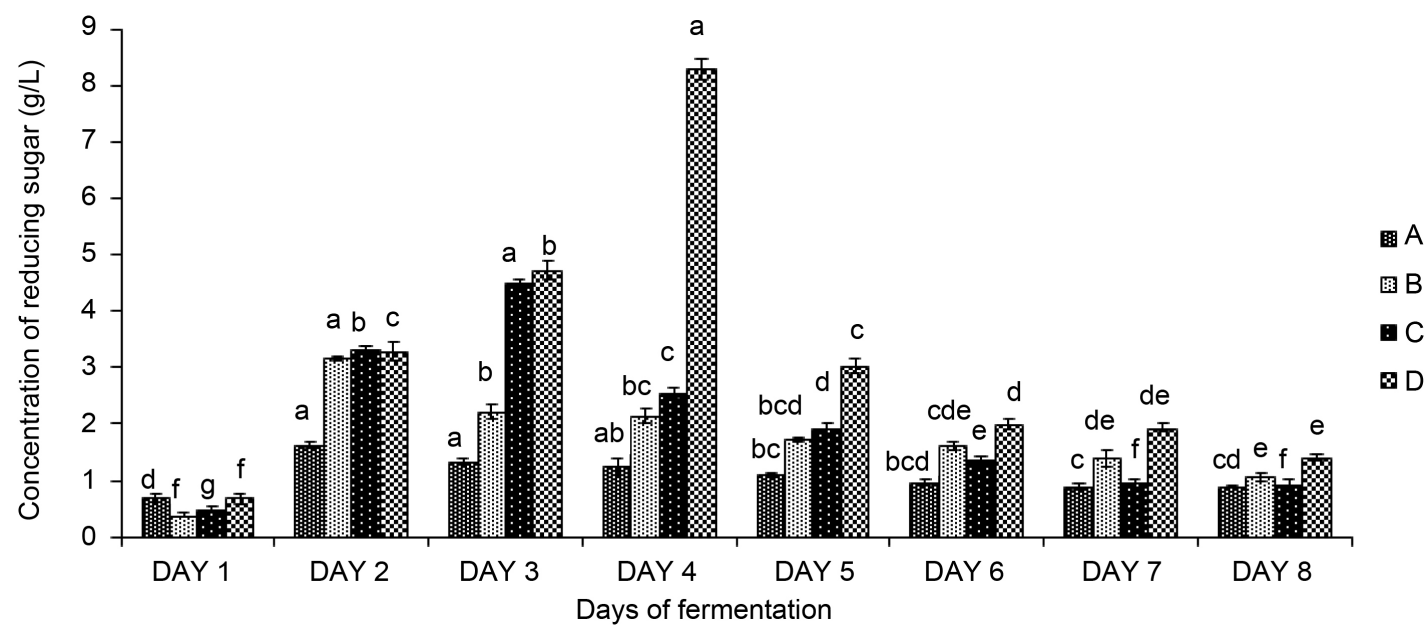

Figure 2. Comprison of reducing sugar concentration in various inoculation treatments during the fermentation process of corn pericarp $-0 \%$ pretreatment. A, B, C and D indicate inoculation treatments with DAY 1 , DAY 2, DAY 3, and DAY 4 inoculation of $S$. cerevisiae. Error bars indicate standard error of the mean (SEM). For each treatment, means with different letters are significantly different $(P<0.05)$.

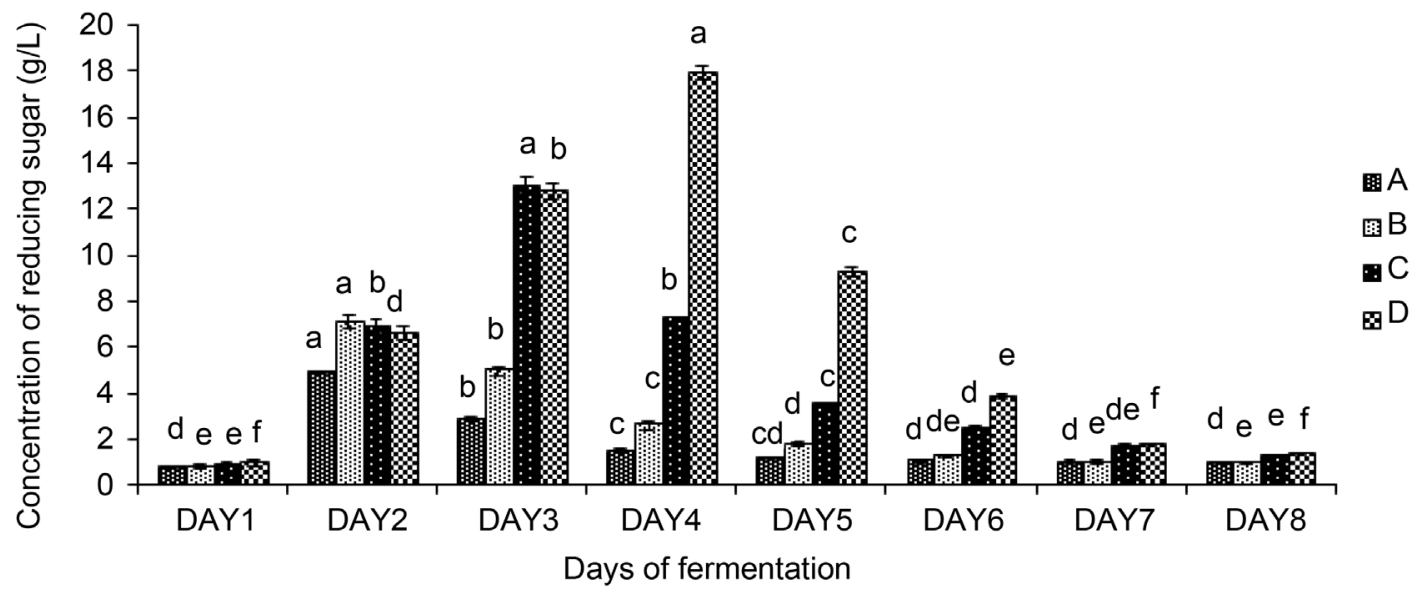

Figure 3. Comprison of reducing sugar concentration in various inoculation treatments during fermentation process of peanut hull $-2.5 \%$ pretreatment. A, B, C and D indicate inoculation treatments with DAY 1, DAY 2, DAY 3, and DAY 4 inoculation of $S$. cerevisiae. Error bars indicate standard error of the mean (SEM). For each treatment, means with different letters are significantly different $(P<0.05)$. 
samples with $\mathrm{H}_{2} \mathrm{O}_{2}$ assisting in the interaction of sugars for the latter conversion to ethanol.

\subsection{Corn Pericarp-Ethanol Yield}

The inoculation treatment $\mathrm{D}$ of $0 \% \mathrm{H}_{2} \mathrm{O}_{2}$ pretreated corn pericarp showed a significantly higher yield of ethanol when compared to other inoculation treatments (Figure 3). In the inoculation treatment $\mathrm{A}$, the fermentation process started on day 1 as it received both $A$. niger and $S$. cerevisiae. But in the case of inoculation treatments B, C and $\mathrm{D}$ the fermentation process started on day 2, day 3 and day 4 because of inoculation of $S$. cerevisiae at one day intervals. The highest concentration of ethanol $(6.79 \mathrm{~g} / \mathrm{L})$ was recorded in inoculation treatment $\mathrm{D}$ on day 8 . This trend was observed with all pretreatments but yields from pretreated samples were higher when compared to control $\left(0 \% \mathrm{H}_{2} \mathrm{O}_{2}\right.$ pretreatment $)$ as seen in Table 1 .

\subsection{Peanut Hull-Ethanol Yield}

Interaction effect of $\mathrm{H}_{2} \mathrm{O}_{2}$ pretreatments and inoculation treatments of peanut hull on ethanol yield were significant (Table 2). Analysis of samples collected on dayl of the fermentation process did not show the presence of ethanol. On day 2, inoculation treatment $\mathrm{A}$ of all the pretreatments $(0 \%, 2.5 \%$ and $5 \%)$ yielded ethanol which was expected as this was the only treatment to have $S$. cerevisiae present. Inoculation treatment $\mathrm{A}$ of $2.5 \%$ gave the highest ethanol yield for day 2 . The highest $(P<0.05)$ amount of ethanol was produced by inoculation treatment A of $2.5 \% \mathrm{H}_{2} \mathrm{O}_{2}$ pretreatment followed by inoculation treatments $\mathrm{B}$ and $\mathrm{C}$ of $2.5 \%$ on day 4 . These inoculation treatments were significantly different $(P<0.05)$ from other treatments in ethanol yield.

Table 1. Interaction effect of days of fermentation, pretreatment and inoculation treatment on ethanol concentration in corn pericarp fermentation process.

\begin{tabular}{|c|c|c|c|c|c|c|c|c|}
\hline Pretreatment & Day 1 & Day 2 & Day 3 & Day 4 & Day 5 & Day 6 & Day 7 & Day 8 \\
\hline $0 \% \mathrm{~A}$ & $0_{\mathrm{F}}^{\mathrm{a}}$ & $1.24_{\mathrm{E}}^{\mathrm{b}}$ & $1.80^{\mathrm{c}}{ }_{\mathrm{DE}}$ & $2.49^{\mathrm{e}} \mathrm{CD}$ & $2.75^{\mathrm{c}}{ }_{\mathrm{BCD}}$ & $3.51^{\mathrm{d}}{ }_{\mathrm{ABC}}$ & $3.63^{\mathrm{e}}{ }_{\mathrm{AB}}$ & $4.48_{\mathrm{A}}^{\mathrm{e}}$ \\
\hline $0 \% \mathrm{~B}$ & $0_{\mathrm{D}}^{\mathrm{a}}$ & $0_{\mathrm{D}}^{\mathrm{c}}$ & $2.11^{c} \mathrm{C}$ & $2.15^{\mathrm{e}} \mathrm{C}$ & $3.42^{\mathrm{c}}{ }_{\mathrm{BC}}$ & $4.00^{\mathrm{d}}{ }_{\mathrm{B}}$ & $4.37^{\mathrm{de}}{ }_{\mathrm{AB}}$ & $5.89^{\mathrm{de}}{ }_{\mathrm{A}}$ \\
\hline $0 \% \mathrm{C}$ & $0^{\mathrm{a}}{ }_{\mathrm{D}}$ & $0^{c}{ }_{D}$ & $0^{\mathrm{d}}{ }_{\mathrm{D}}$ & $2.50^{\mathrm{e}}{ }_{\mathrm{C}}$ & $3.31^{\mathrm{c}}{ }_{\mathrm{BC}}$ & $3.82^{\mathrm{d}}{ }_{\mathrm{AB}}$ & $4.48^{\mathrm{de}}{ }_{\mathrm{AB}}$ & $4.79^{\mathrm{de}}{ }_{\mathrm{A}}$ \\
\hline $0 \% \mathrm{D}$ & $0^{\mathrm{a}}{ }_{\mathrm{E}}$ & $0_{\mathrm{E}}^{\mathrm{c}}$ & $0_{\mathrm{E}}^{\mathrm{d}}$ & $0_{\mathrm{E}}^{\mathrm{f}}$ & $3.91^{c}{ }_{D}$ & $4.91_{C}^{\mathrm{d}}$ & $5.96^{\mathrm{d}}{ }_{\mathrm{B}}$ & $6.79^{\mathrm{d}}{ }_{\mathrm{A}}$ \\
\hline $2.5 \% \mathrm{~A}$ & $0^{\mathrm{a}}{ }_{\mathrm{G}}$ & $5.52^{\mathrm{a}}{ }_{\mathrm{F}}$ & $10.24^{\mathrm{a}}$ & $13.31^{\mathrm{a}}{ }_{\mathrm{D}}$ & $14.39^{\mathrm{ab}} \mathrm{CD}$ & $15.54^{\mathrm{bc}}{ }_{\mathrm{BC}}$ & $16.70^{\mathrm{b}}{ }_{\mathrm{AB}}$ & $18.09^{\mathrm{b}}{ }_{\mathrm{A}}$ \\
\hline $2.5 \% \mathrm{~B}$ & $0^{\mathrm{a}}{ }_{\mathrm{E}}$ & $0_{\mathrm{E}}^{\mathrm{c}}$ & $6.37^{\mathrm{b}}{ }_{\mathrm{D}}$ & $11.53^{\mathrm{b}} \mathrm{C}$ & $13.69^{\mathrm{ab}}{ }_{\mathrm{B}}$ & $14.37^{\mathrm{c}}{ }_{\mathrm{B}}$ & $16.77_{\mathrm{A}}^{\mathrm{b}}$ & $17.82^{\mathrm{b}}{ }_{\mathrm{A}}$ \\
\hline $2.5 \% \mathrm{C}$ & $0^{\mathrm{a}}{ }_{\mathrm{D}}$ & $0_{D}^{c}$ & $0^{\mathrm{d}}{ }_{\mathrm{D}}$ & $9.13^{\mathrm{cd}}$ & $16.53^{\mathrm{a}}{ }_{\mathrm{B}}$ & $17.53^{\mathrm{ab}}{ }_{\mathrm{B}}$ & $21.55^{\mathrm{a}}{ }_{\mathrm{A}}$ & $22.20^{\mathrm{a}}{ }_{\mathrm{A}}$ \\
\hline $2.5 \% \mathrm{D}$ & $0^{\mathrm{a}}{ }_{\mathrm{C}}$ & $0^{c}{ }_{C}$ & $0^{\mathrm{d}}{ }_{\mathrm{C}}$ & $0_{\mathrm{C}}^{\mathrm{f}}$ & $11.43^{\mathrm{b}}$ & $19.62^{\mathrm{a}}{ }_{\mathrm{A}}$ & $20.09^{\mathrm{a}}{ }_{\mathrm{A}}$ & $21.78^{\mathrm{a}}{ }_{\mathrm{A}}$ \\
\hline $5 \% \mathrm{~A}$ & $0_{\mathrm{E}}^{\mathrm{a}}$ & $5.51^{\mathrm{a}}{ }_{\mathrm{D}}$ & $9.29^{\mathrm{a}}{ }_{\mathrm{C}}$ & $11.82^{\mathrm{b}}{ }_{\mathrm{B}}$ & $13.80^{\mathrm{ab}}{ }_{\mathrm{A}}$ & $14.67_{\mathrm{A}}^{\mathrm{c}}$ & $14.76_{\mathrm{A}}^{\mathrm{c}}$ & $14.92^{\mathrm{c}} \mathrm{A}$ \\
\hline $5 \% \mathrm{~B}$ & $0^{\mathrm{a}}{ }_{\mathrm{E}}$ & $0_{\mathrm{E}}^{\mathrm{c}}$ & $5.68_{\mathrm{D}}^{\mathrm{b}}$ & $10.47^{b c}$ & $12.90^{\mathrm{ab}}{ }_{\mathrm{B}}$ & $13.95^{\mathrm{c}}{ }_{\mathrm{A}}$ & $14.29^{\mathrm{c}}{ }_{\mathrm{A}}$ & $14.55^{\mathrm{c}}{ }_{\mathrm{A}}$ \\
\hline $5 \% \mathrm{C}$ & $0_{\mathrm{E}}^{\mathrm{a}}$ & $0_{\mathrm{E}}^{c}$ & $0_{\mathrm{E}}^{\mathrm{d}}$ & $8.14_{D}^{\mathrm{d}}$ & $12.12^{\mathrm{b}} \mathrm{C}$ & $15.18^{c}{ }_{B}$ & $17.17_{\mathrm{A}}^{\mathrm{b}}$ & $18.73_{\mathrm{A}}^{\mathrm{b}}$ \\
\hline $5 \% \mathrm{D}$ & $0^{\mathrm{a}}{ }_{\mathrm{D}}$ & $0^{\mathrm{c}}{ }_{\mathrm{D}}$ & $0^{\mathrm{d}}{ }_{\mathrm{D}}$ & $0_{\mathrm{D}}^{\mathrm{f}}$ & $10.66^{\mathrm{b}}{ }_{\mathrm{C}}$ & $15.89^{b c} c_{B}$ & $18.16^{\mathrm{b}}{ }_{\mathrm{A}}$ & $19.14_{\mathrm{A}}^{\mathrm{b}}$ \\
\hline
\end{tabular}

${ }^{\mathrm{abc}}$ Means within the same row followed by a different superscript letter are significantly different $(P<0.05){ }_{\mathrm{ABC}}$ Means within the same column followed by a different subscript letter are significantly different $(P<0.05)$. 
Table 2. Data analysis report for the interaction effects of days of fermentation, pretreatment and inoculation treatment on ethanol concentration in peanut hull fermentation process.

\begin{tabular}{|c|c|c|c|c|c|c|c|c|}
\hline Pretreatment & Day 1 & Day 2 & Day 3 & Day 4 & Day 5 & Day 6 & Day 7 & Day 8 \\
\hline $0 \% \mathrm{~A}$ & $0^{\mathrm{a}}{ }_{\mathrm{D}}$ & $0.99^{c} \mathrm{CD}$ & $1.57^{\mathrm{d}}{ }_{\mathrm{BC}}$ & $1.99^{\mathrm{g}} \mathrm{ABC}$ & $2.32^{\mathrm{e}}{ }_{\mathrm{AB}}$ & $2.56^{\mathrm{e}}{ }_{\mathrm{AB}}$ & $2.68_{\mathrm{A}}^{\mathrm{f}}$ & $2.84_{\mathrm{A}}^{\mathrm{f}}$ \\
\hline $0 \% \mathrm{~B}$ & $0^{\mathrm{a}}{ }_{\mathrm{F}}$ & $0_{\mathrm{F}}^{\mathrm{c}}$ & $1.63_{\mathrm{E}}^{\mathrm{d}}$ & $2.17^{\mathrm{fg}}$ & $2.59^{\mathrm{de}}{ }_{\mathrm{CD}}$ & $2.80^{\mathrm{e}}{ }_{\mathrm{BC}}$ & $3.18_{\mathrm{AB}}^{\mathrm{f}}$ & $3.30^{\mathrm{e}}{ }_{\mathrm{A}}$ \\
\hline $0 \% \mathrm{C}$ & $0^{\mathrm{a}}{ }_{\mathrm{D}}$ & $0_{\mathrm{D}}^{\mathrm{c}}$ & $0_{\mathrm{D}}^{\mathrm{e}}$ & $1.61^{\mathrm{g}} \mathrm{C}$ & $2.23^{\mathrm{e}}{ }_{\mathrm{BC}}$ & $2.78^{\mathrm{e}}{ }_{\mathrm{AB}}$ & $3.10_{\mathrm{AB}}^{\mathrm{f}}$ & $3.42^{\mathrm{e}} \mathrm{A}$ \\
\hline $0 \% \mathrm{D}$ & $0^{\mathrm{a}}{ }_{\mathrm{C}}$ & $0^{c}{ }_{C}$ & $0^{\mathrm{e}}{ }_{\mathrm{C}}$ & $0^{\mathrm{h}}{ }_{\mathrm{C}}$ & $1.88^{\mathrm{e}}{ }_{\mathrm{B}}$ & $2.66^{\mathrm{e}}{ }_{\mathrm{AB}}$ & $3.24_{\mathrm{A}}^{\mathrm{f}}$ & $3.43^{\mathrm{e}}$ \\
\hline $2.5 \% \mathrm{~A}$ & $0^{\mathrm{a}}{ }_{\mathrm{D}}$ & $3.26^{\mathrm{a}}{ }_{\mathrm{C}}$ & $5.30^{\mathrm{a}}{ }_{\mathrm{BC}}$ & $6.28^{\mathrm{a}}{ }_{\mathrm{AB}}$ & $6.90^{\mathrm{a}}{ }_{\mathrm{AB}}$ & $7.55^{\mathrm{abc}}{ }_{\mathrm{AB}}$ & $7.72^{\mathrm{bc}}{ }_{\mathrm{AB}}$ & $8.09^{\mathrm{bc}}{ }_{\mathrm{A}}$ \\
\hline $2.5 \% \mathrm{~B}$ & $0_{\mathrm{E}}^{\mathrm{a}}$ & $0_{\mathrm{E}}^{\mathrm{c}}$ & $3.00^{b c}$ & $4.80^{b c}$ & $5.83^{\mathrm{ab}}{ }_{\mathrm{B}}$ & $6.94^{\mathrm{bcd}}{ }_{\mathrm{A}}$ & $6.99_{\mathrm{A}}^{\mathrm{cd}}$ & $7.44^{\mathrm{cd}}{ }_{\mathrm{A}}$ \\
\hline $2.5 \% \mathrm{C}$ & $0^{\mathrm{a}}{ }_{\mathrm{E}}$ & $0_{\mathrm{E}}^{\mathrm{c}}$ & $0_{\mathrm{E}}^{\mathrm{e}}$ & $5.02^{\mathrm{b}}{ }_{\mathrm{D}}$ & $7.13^{\mathrm{a}}{ }_{\mathrm{C}}$ & $8.61^{\mathrm{ab}}{ }_{\mathrm{B}}$ & $9.21_{\mathrm{AB}}^{\mathrm{ab}}$ & $9.73^{\mathrm{ab}}{ }_{\mathrm{A}}$ \\
\hline $2.5 \% \mathrm{D}$ & $0^{\mathrm{a}}{ }_{\mathrm{C}}$ & $0_{C}^{c}$ & $0^{\mathrm{e}}$ & $0^{\mathrm{h}}{ }_{\mathrm{C}}$ & $6.14^{\mathrm{a}}{ }_{\mathrm{B}}$ & $9.55^{\mathrm{a}}{ }_{\mathrm{A}}$ & $9.80^{\mathrm{a}}{ }_{\mathrm{A}}$ & $10.38^{\mathrm{a}}{ }_{\mathrm{A}}$ \\
\hline $5 \% \mathrm{~A}$ & $0_{\mathrm{E}}^{\mathrm{a}}$ & $1.96^{\mathrm{b}}{ }_{\mathrm{D}}$ & $3.46^{\mathrm{b}}{ }_{\mathrm{C}}$ & $4.09^{\mathrm{cd}}{ }_{\mathrm{BC}}$ & $4.66^{\mathrm{bc}}{ }_{\mathrm{ABC}}$ & $5.12^{\mathrm{d}}{ }_{\mathrm{AB}}$ & $5.32^{\mathrm{e}}{ }_{\mathrm{AB}}$ & $5.651^{\mathrm{d}}{ }_{\mathrm{A}}$ \\
\hline $5 \% \mathrm{~B}$ & $0^{\mathrm{a}}{ }_{\mathrm{D}}$ & $0_{\mathrm{D}}^{\mathrm{c}}$ & $2.28^{\mathrm{cd}}{ }_{\mathrm{C}}$ & $3.33^{\mathrm{de}}{ }_{B C}$ & $4.61^{\mathrm{bc}}{ }_{\mathrm{AB}}$ & $5.07^{\mathrm{d}}{ }_{\mathrm{AB}}$ & $5.33_{\mathrm{A}}^{\mathrm{e}}$ & $5.7^{\mathrm{d}}{ }_{\mathrm{A}}$ \\
\hline $5 \% \mathrm{C}$ & $0^{\mathrm{a}}{ }_{\mathrm{D}}$ & $0_{\mathrm{D}}^{\mathrm{c}}$ & $0_{\mathrm{D}}^{\mathrm{e}}$ & $2.81^{\mathrm{ef}}{ }_{\mathrm{C}}$ & $4.12^{\mathrm{c}}{ }_{\mathrm{B}}$ & $5.23^{\mathrm{d}}{ }_{\mathrm{AB}}$ & $5.40_{\mathrm{A}}^{\mathrm{e}}$ & $5.95^{\mathrm{d}}{ }_{\mathrm{A}}$ \\
\hline $5 \% \mathrm{D}$ & $0^{\mathrm{a}}{ }_{\mathrm{C}}$ & $0^{c}{ }_{C}$ & $0^{\mathrm{e}}{ }_{\mathrm{C}}$ & $0^{\mathrm{h}}{ }_{\mathrm{C}}$ & $3.79^{c d}{ }_{B}$ & $5.62_{\mathrm{A}}^{\mathrm{cd}}$ & $5.96^{\mathrm{de}}{ }_{\mathrm{A}}$ & $6.52^{\mathrm{cd}}{ }_{\mathrm{A}}$ \\
\hline
\end{tabular}

${ }^{\mathrm{abc}}$ Means within the same row followed by a different superscript letter are significantly different $(P<0.05)$. ${ }_{\mathrm{A}, \mathrm{B}, \mathrm{C}}$ Means within the same column followed by a different subscript letter are significantly different $(P<0.05)$.

These data display that there is a compensatory gain between samples when $S$. cerevisiae is added after $A$. niger has started the breakdown of samples. This is beneficial knowledge as a continuous process would not be hindered due to day of inoculation.

\subsection{Data Analysis between Corn Pericarp and Peanut Hull}

Data in Table 3 display that the highest production of ethanol occurred in samples pretreated at the $2.5 \% \mathrm{H}_{2} \mathrm{O}_{2}$ with the steepest slope of production between days 3 and 4 for most treatments.

\subsection{Cost Analysis for Ethanol Production}

There was a lab scale cost difference between a pound of raw materials, corn pericarp costs $\$ 5.33$ versus $\$ 0.08$ for peanut hull. Corn pericarp was able to produce higher ethanol yield than peanut hull, $22.2 \mathrm{~g} / \mathrm{L}$ versus $10.3 \mathrm{~g} / \mathrm{L}$ respectively. Calculating cost of production for the ethanol, corn pericarp was able to produce more ethanol but the cost of production was higher. On a lab scale, a gallon of ethanol from corn utilizing these methods costs $\$ 204.78$ while a gallon from peanut hull costs $\$ 136.88$. These costs are extreme, but are based upon lab scale purchases for reagents. If produced and calculated on a large scale the price per gallon drops to $\$ 2.39$ for corn pericarp and $\$ 2.32$ for peanut hull. The reason for the price difference for the substrates is the amount of reagents used to produce the gallon of ethanol and the yield of ethanol from those substrates, higher amounts for both for production with corn pericarp.

\section{Conclusion}

Lignin acts as a barrier of action for saccharifying enzymes and fermentation enzymes; 
Table 3. Data analysis report for the interaction effects of corn pericarp and peanut hull on ethanol concentration during fermentation process.

\begin{tabular}{|c|c|c|c|c|c|c|c|c|}
\hline $\begin{array}{l}\text { Treatment by } \\
\text { pretreatment }\end{array}$ & Day 1 & Day 2 & Day 3 & Day 4 & Day 5 & Day 6 & Day 7 & Day 8 \\
\hline CP 0\% A & $0^{\mathrm{a}}$ & $1.24^{\mathrm{d}}$ & $1.81^{\mathrm{f}}$ & $2.49^{\mathrm{hi}}$ & $2.76^{\mathrm{h}}$ & $3.52^{\text {hij }}$ & $3.64^{\mathrm{ij}}$ & $4.48^{\mathrm{ij}}$ \\
\hline CP 0\% B & $0^{\mathrm{a}}$ & $0^{\mathrm{e}}$ & $2.12^{\mathrm{ef}}$ & $2.16^{\mathrm{hi}}$ & $3.43^{\mathrm{gh}}$ & $4.01^{\mathrm{hij}}$ & $4.37^{\mathrm{hij}}$ & $5.89^{\text {ghi }}$ \\
\hline CP 0\% C & $0^{\mathrm{a}}$ & $0^{\mathrm{e}}$ & $0^{g}$ & $2.51^{\mathrm{hi}}$ & $3.32^{\mathrm{gh}}$ & $3.82^{\mathrm{hij}}$ & $4.48^{\mathrm{hij}}$ & $4.79^{\text {hij }}$ \\
\hline CP 0\% D & $0^{\mathrm{a}}$ & $0^{\mathrm{e}}$ & $0^{g}$ & $0^{j}$ & $3.91^{\mathrm{gh}}$ & $4.91^{\text {ghi }}$ & $5.96^{\mathrm{fgh}}$ & $6.79^{\mathrm{fgh}}$ \\
\hline $\mathrm{CP} 2.5 \% \mathrm{~A}$ & $0^{\mathrm{a}}$ & $5.52^{\mathrm{a}}$ & $10.24^{\mathrm{a}}$ & $13.32^{\mathrm{a}}$ & $14.41^{\mathrm{ab}}$ & $15.55^{\mathrm{bc}}$ & $16.71^{\mathrm{b}}$ & $18.09^{\mathrm{b}}$ \\
\hline CP $2.5 \% \mathrm{~B}$ & $0^{\mathrm{a}}$ & $0^{\mathrm{e}}$ & $6.37^{\mathrm{b}}$ & $11.53^{b c}$ & $13.69^{\mathrm{bc}}$ & $14.37^{\mathrm{c}}$ & $16.78^{\mathrm{b}}$ & $17.82^{\mathrm{b}}$ \\
\hline CP $2.5 \%$ C & $0^{\mathrm{a}}$ & $0^{\mathrm{e}}$ & $0^{\mathrm{g}}$ & $9.14^{\mathrm{d}}$ & $16.51^{\mathrm{a}}$ & $17.53^{\mathrm{b}}$ & $21.55^{\mathrm{a}}$ & $22.21^{\mathrm{a}}$ \\
\hline CP $2.5 \% \mathrm{D}$ & $0^{\mathrm{a}}$ & $0^{\mathrm{e}}$ & $0^{\mathrm{g}}$ & $0^{j}$ & $11.44^{\mathrm{cd}}$ & $19.63^{\mathrm{a}}$ & $20.09^{\mathrm{a}}$ & $21.78^{\mathrm{a}}$ \\
\hline CP 5\% A & $0^{\mathrm{a}}$ & $5.51^{\mathrm{a}}$ & $9.31^{\mathrm{a}}$ & $11.82^{\mathrm{b}}$ & $13.81^{\mathrm{bc}}$ & $14.67^{\mathrm{c}}$ & $14.76^{\mathrm{c}}$ & $14.93^{\mathrm{c}}$ \\
\hline CP 5\% B & $0^{\mathrm{a}}$ & $0^{\mathrm{e}}$ & $5.68^{\mathrm{bc}}$ & $10.48^{\mathrm{c}}$ & $12.91^{\mathrm{bcd}}$ & $13.95^{\mathrm{c}}$ & $14.29^{c}$ & $14.55^{\mathrm{c}}$ \\
\hline CP $5 \% \mathrm{C}$ & $0^{\mathrm{a}}$ & $0^{\mathrm{e}}$ & $0^{\mathrm{g}}$ & $8.15^{\mathrm{d}}$ & $12.12^{\mathrm{bcd}}$ & $15.19^{c}$ & $17.17^{\mathrm{b}}$ & $18.74^{\mathrm{b}}$ \\
\hline CP 5\% D & $0^{\mathrm{a}}$ & $0^{\mathrm{e}}$ & $0^{g}$ & $0^{j}$ & $10.66^{\mathrm{d}}$ & $15.89^{\mathrm{bc}}$ & $18.16^{\mathrm{b}}$ & $19.14^{\mathrm{b}}$ \\
\hline $\mathrm{PH} \mathrm{0 \%} \mathrm{A}$ & $0^{\mathrm{a}}$ & $0.99^{\mathrm{d}}$ & $1.58^{\mathrm{f}}$ & $1.99^{\mathrm{i}}$ & $2.32^{\mathrm{h}}$ & $2.57^{\mathrm{j}}$ & $2.68^{j}$ & $2.84^{\mathrm{j}}$ \\
\hline PH 0\% B & $0^{\mathrm{a}}$ & $0^{\mathrm{e}}$ & $1.63^{\mathrm{f}}$ & $2.17^{\mathrm{hi}}$ & $2.59^{\mathrm{h}}$ & $2.81^{\mathrm{ij}}$ & $3.18^{\mathrm{j}}$ & $3.31^{\mathrm{j}}$ \\
\hline PH $0 \% \mathrm{C}$ & $0^{\mathrm{a}}$ & $0^{\mathrm{e}}$ & $0^{\mathrm{g}}$ & $1.61^{\mathrm{i}}$ & $2.24^{\mathrm{h}}$ & $2.79^{\mathrm{ij}}$ & $3.11^{j}$ & $3.43^{j}$ \\
\hline PH 0\% D & $0^{\mathrm{a}}$ & $0^{\mathrm{e}}$ & $0^{g}$ & $0^{j}$ & $1.89^{\mathrm{h}}$ & $2.66^{j}$ & $3.24^{j}$ & $3.43^{j}$ \\
\hline PH $2.5 \% \mathrm{~A}$ & $0^{\mathrm{a}}$ & $3.27^{\mathrm{b}}$ & $5.31^{\mathrm{c}}$ & $4.81^{\mathrm{f}}$ & $6.91^{\mathrm{ef}}$ & $7.55^{\mathrm{def}}$ & $7.72^{\mathrm{ef}}$ & $8.09^{\mathrm{ef}}$ \\
\hline PH $2.5 \%$ B & $0^{\mathrm{a}}$ & $0^{\mathrm{e}}$ & $3.01^{\mathrm{de}}$ & $6.28^{\mathrm{e}}$ & $5.84^{\mathrm{efg}}$ & $6.95^{\mathrm{efg}}$ & $6.99^{\mathrm{fg}}$ & $7.45^{\mathrm{fg}}$ \\
\hline PH $2.5 \%$ C & $0^{\mathrm{a}}$ & $0^{\mathrm{e}}$ & $0^{g}$ & $5.03^{\mathrm{f}}$ & $7.14^{\mathrm{e}}$ & $8.62^{\mathrm{de}}$ & $9.22^{\mathrm{de}}$ & $9.73^{\mathrm{de}}$ \\
\hline $\mathrm{PH} 2.5 \% \mathrm{D}$ & $0^{\mathrm{a}}$ & $0^{\mathrm{e}}$ & $0^{g}$ & $0^{j}$ & $6.14^{\mathrm{efg}}$ & $9.55^{\mathrm{d}}$ & $9.81^{\mathrm{d}}$ & $10.38^{\mathrm{d}}$ \\
\hline PH 5\% A & $0^{\mathrm{a}}$ & $1.97^{\mathrm{c}}$ & $3.46^{\mathrm{d}}$ & $4.09^{\mathrm{fg}}$ & $4.66^{\mathrm{efgh}}$ & $5.13^{\mathrm{gh}}$ & $5.33^{\text {ghi }}$ & $5.65^{\text {ghi }}$ \\
\hline PH 5\% B & $0^{\mathrm{a}}$ & $0^{\mathrm{e}}$ & $2.29^{\mathrm{ef}}$ & $3.34^{\mathrm{gh}}$ & $4.62^{\text {efgh }}$ & $5.08^{\text {gh }}$ & $5.34^{\text {ghi }}$ & $5.71^{\text {ghi }}$ \\
\hline PH 5\% C & $0^{\mathrm{a}}$ & $0^{\mathrm{e}}$ & $0^{\mathrm{g}}$ & $2.82^{\mathrm{hi}}$ & $4.13^{\mathrm{fgh}}$ & $5.24^{\mathrm{gh}}$ & $5.41^{\mathrm{ghi}}$ & $5.95^{\mathrm{ghi}}$ \\
\hline PH 5\% D & $0^{\mathrm{a}}$ & $0^{\mathrm{e}}$ & $0^{\mathrm{g}}$ & $0^{j}$ & $3.81^{\mathrm{gh}}$ & $5.63^{\mathrm{fgh}}$ & $5.96^{\mathrm{fgh}}$ & $6.52^{\mathrm{fgh}}$ \\
\hline
\end{tabular}

${ }^{\mathrm{abc}}$ Means within the same column followed by a different superscript letter are significantly different $(P<0.05)$.CP is corn pericarp. PH is peanut hull. A, B, C, and D represent the day of inoculation $1-4$, respectively.

thus ethanol production is limited without pretreatment. Generally the economic feasibility of the ethanol production technology depends purely on the extent to which and how much sugar molecules are generated from the substrate.

This study compared three concentrations of alkaline hydrogen peroxide pretreatment on reducing sugars and production of ethanol from peanut hull and corn pericarp samples. In both substrates, pretreatment using hydrogen peroxide concentration of $2.5 \%$ was more efficient in removing lignin, compared to $0 \%$ and $5 \%$ concentrations. The measurement of reducing sugars prior to fermentation revealed that the advantage of a pretreatment as a 2 - 3 fold increase was recorded when compared to $0 \%$ pretreatment. Due to the removal or reduction of lignin content, the pretreatment steps increased the sugar yield during hydrolysis of both substrates. 
Inoculation treatments day 3 and day 4 of corn pericarp and day 4 of peanut hull with $2.5 \% \mathrm{H}_{2} \mathrm{O}_{2}$ pretreatment yielded the highest ethanol concentrations. The highest yields of ethanol obtained for corn pericarp and peanut hull were $45.04 \%$ and $24.6 \%$ respectively. Cost assessment of the ethanol production process with lignocellulosic material indicated that while both corn pericarp and peanut hull could be used as substrates, although at a small scale this is cost prohibitive.

\section{Acknowledgements}

This project recognizes input from Oladiran Fasina at Auburn University for substrate provision Thilini Ranatungaat Alabama A\&M University for fermentation assistance and analysis, the Alabama Agricultural Land Grant Alliance (AALGA) and the Alabama A\&M University College of Agricultural, Life and Natural Sciences.

\section{Conflict of Interest}

We declare that we have no conflict of interest.

\section{References}

[1] Economic Research Service (ERS), U.S. Department of Agriculture (USDA) (2016) Food Price Outlook. http://www.ers.usda.gov/data-products/food-price-outlook.aspx

[2] U.S. Energy Information Administration (2016) Short-Term Energy Outlook. https://www.eia.gov/forecasts/steo/report/us_oil.cfm

[3] ASPO (2006) The Association for the Study of Peak Oil and Gas. Newsletter No. 61. http://www.aspo-ireland.org/contentFiles/newsletterPDFs/newsletter61.pdf

[4] Morrison, R.M. (2016) USDA ERS. Food Prices and Spending. http://www.ers.usda.gov/data-products/ag-and-food-statistics-charting-the-essentials/foodprices-and-spending.aspx

[5] Chen, S.T., Kuo, H.I. and Chen, C.C. (2010) Modeling the Relationship between the Oil Price and Global Food Prices. Applied Energy, 87, 2517-2525. http://dx.doi.org/10.1016/j.apenergy.2010.02.020

[6] Abouzied, M.M. and Reddy, C.A. (1986) Direct Fermentation of Potato Starch to Ethanol by Co-Cultures of Aspergillus niger and Saccharomyces cerevisiae. Applied and Environmental Microbiology, 52, 1055-1059.

[7] Tang, Y., An, M., Liu, K., Nagai, S., Shigematsu, T., Morimura, S. and Kida, K. (2006) Ethanol Production from Acid Hydrolysate of Wood Biomass Using the Flocculating Yeast Saccharomyces cerevisiae Strain KF-7. Process Biochemistry, 41, 909-914. http://dx.doi.org/10.1016/j.procbio.2005.09.008

[8] Ross, A.F. (1959) Dinitrophenol Method for Reducing Sugars. Potato Processing, 1, $492-$ 493.

[9] Shen, Y., Zhang, Y., Ma, T., Bao, X., Du, F., Zhuang, G. and Qu, Y. (2008) Simultaneous Saccharification and Fermentation of Acid-Pretreated Corncobs with a Recombinant Saccharomyces cerevisiae Expressing b-Glucosidase. Bioresource Technology, 99, 5099-5103. http://dx.doi.org/10.1016/j.biortech.2007.09.046

[10] Bai, F.W., Anderson, W.A. and Young, M.M. (2008) Ethanol Fermentation Technologies from Sugar and Starch Feed Stocks. Biotechnology Advances, 26, 89-105. http://dx.doi.org/10.1016/j.biotechadv.2007.09.002 
[11] Zhu, S., Wu, Y., Yu, Z., Zhang, X., Wang, C., Yu, F. and Jin, S. (2006) Production of Ethanol from Microwave-Assisted Alkali Pretreated Wheat Straw. Process Biochemistry, 41, 869-873. http://dx.doi.org/10.1016/j.procbio.2005.10.024

[12] Dawson, L. and Boopathy, R. (2007) Use of Post-Harvest Sugarcane Residue for Ethanol Production. Bioresource Technology, 98, 1695-1699. http://dx.doi.org/10.1016/j.biortech.2006.07.029

[13] Gould, J.M. (1984) Alkaline Peroxide Delignification of Agricultural Residues to Enhance Enzymatic Saccharification. Biotechnology and Bioengineering, 26, 46-52. http://dx.doi.org/10.1002/bit.260260110

[14] Dalimova, G.N. (2005) Oxidation of Hydrolyzed Lignin from Cotton-Seed Husks by Hydrogen Peroxide. Chemistry of Natural Compounds, 41, 85-87. http://dx.doi.org/10.1007/s10600-005-0081-3

[15] Krishna, S.H. and Chowdary, G.V. (2000) Optimization of Simultaneous Saccharification and Fermentation for the Production of Ethanol from Lignocellulosic Biomass. Journal of Agricultural and Food Chemistry, 48, 1971-1976. http://dx.doi.org/10.1021/jf991296z

[16] Sewalt, V.J.H., Glasser, W.G. and Beauchemin, K.A. (1997) Lignin Impact on Fiber Degradation: Reversal of Inhibition on Enzymatic Hydrolysis by Chemical Modification of Lignin and by Additives. Journal of Agricultural and Food Chemistry, 45, 1823-1828. http://dx.doi.org/10.1021/jf9608074

[17] Kang, S.W., Park, Y.S., Lee, J.S., Hong, S.I. and Kim, S.W. (2004) Production of Cellulases and Hemicellulases by Aspergillus niger KK2 from Lignocellulosic Biomass. Bioresource Technology, 91, 153-156. http://dx.doi.org/10.1016/S0960-8524(03)00172-X

\section{Submit or recommend next manuscript to SCIRP and we will provide best service for you:}

Accepting pre-submission inquiries through Email, Facebook, LinkedIn, Twitter, etc.

A wide selection of journals (inclusive of 9 subjects, more than 200 journals)

Providing 24-hour high-quality service

User-friendly online submission system

Fair and swift peer-review system

Efficient typesetting and proofreading procedure

Display of the result of downloads and visits, as well as the number of cited articles

Maximum dissemination of your research work

Submit your manuscript at: http://papersubmission.scirp.org/

Or contact fns@scirp.org 